\title{
ОЛИГАРХЖСАН УЛС ТӨРИЙН НАМААС НАМГУЙ НИЙГЭМД ШИЛЖИХ ЦАГ БИДНИЙ ТӨСӨӨЛЖ БАЙГААГААС ИЛУУ ОЙРХОН Ч БАЙЖ МЭДНЭ
}

\author{
Д.Баасансурэн \\ ${ }^{1}$ ШУА-ийн Философийн хүрээлэнгийн Улс төр судлалын салбар \\ Монгол улс \\ Цахим шуудан: dugbaaska2010@yahoo.com
}

СУҮлийн жилүҮдэд улс төрийн намыг өөрчлөн байгуулах, шинэчлэх тухай асуудал эрчимтэй яригдсаар ирлээ. Аливаа улс төрийн нам иөөнхийн эрх мэдэлд орж олигархжих хувь тавилан, зүй тогтолтой.Улс төрийн намыг ицааиид хэрхэх талаарх олон нийтийн үзэл бодол, байр суурийн зөруүтэй байдал нь аажмаар арилж, ижил төстөй санаа бодол руу ойртох хандлага ажиглагдаж буй нь намгүй нийгэмд шилжих иаг бидний төсөөлж байгаагаас илүү ойрхон ч байж мэднэ.

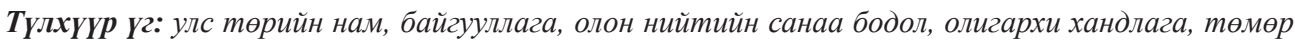
хууль, намгүй нийгэм

Сүүлийн жилүүдэд улс төрийн намыг өөрчлөн байгуулах, шинэчлэх тухай асуудал эрчимтэй яригдсаар ирлээ. Улс төрийн байгууллагын шинэчлэлийн асуудлаар улс төрчид болон иргэдийн санаа бодол ихээхэн ялгаатай байсан ч аажмаар ойртох хандлага ажиглагдах болов.

Өнгөрсөн хорь гаруй жилийн хугацаанд Монголын голлох намууд шинэчлэлийн асуудлыг сүр дуулиантай эхлүүлдэг боловч харамсалтай нь тэгсгээд боловсон хүчний халаа сэлгээ болон замхардаг зуршил тогтжээ. Намаа шинэчлэх эдгээр давалгаа, хөдөлгөөний нэг үндсэн зорилго нь “улс төрийн намыг олигархаас иэвэрлэх", далбаан дор өрнөж, шүүмжлэлийн гол бай нь олигархжих үзэгдэл болдог.

Иймд энэхүу өгүүлэлд улс төрийн намын олигархижих хандлага зүй ёсны үзэгдэл мөн эсэхийг германы нэрт эрдэмтэн Р.Михельсийн судалгаa шинжилгээнд тулгуурлан цаашид хэрхэхийг олон нийтийн санаа бодлыг судлан тодруулах үндсэн дээр хэтдээ байж болох хувилбарыг авч үзэхийг зорьсон болно.

Эхлээд тус өгүүлэлд хэрэглэгдэх үндсэн ойлголтын утга агуулгыг тодорхойлох нь зүйн хэрэг. Англиар "oligarchiy", оросоор “олигархия" хэмээх үг нь “цөөнхийн засаглал" буюу "баячуудын засаглал"1 гэж монгол хэлээр хөрвүүлэгддэг бол засаглал, эрх мэдэл хэсэг бүлэг хүмүүсийн гарт, нийгмийн баялаг цөөн гэр бүлийн хүрээнд төвлөрсөн улс төрийн дэглэм болохыг улс төрийн толь бичгүүдэд тодорхойлсон байна. ${ }^{2}$

Тэгэхээр улс төрийн намын олигархжих онол гэдэг нь улс төрийн шинжлэх ухаанд нийгмийн бүтцийн ардчилсан хэв маягаас олон шат дамжлагатай хүнд сурталжсан (бюрократ) нүсэр аппарат бүхий бүтэц зохион байгуулалтад шилжих өвөрмөц

1. Ё.Довчин Улс төрийн үг хэллэг нэр томьёоны толь. УБ., 2005., 158 дахь тал.

2. Краткий политтический словарь.-М.2009.,Современная западная соииология словарь.-М., 1990 зэргээс Узнэ $Y Y$. 
Үзэгдэлийг судлан тайлбарладаг “олигархи хандлагын төмөр хууль” (“железный закон олигархизачии”, “Iгоn law of oligarchy”) гэгчийг германы улс төр судлаач Р.Михельс тэртээ 1911 онд анх дэвшүүлэн шинжлэх ухааны эргэлтэд оруулсан гэдэг.

Оросын судлаач М. Острогорский “Ардчилал ба улс төрийн намын зохион байгуулалт"3 хэмээх бүтээлдээ энэхүY онолын судалгаанд шинэ салхи оруулж, улс төрийн намын эрх баригч дээд байгууллага нь олон түмний намыг бюрократчилагдсан буюу ардчилсан бус бүтэц болгон хувиргадаг болохыг нотолсон байдаг. Түүний үзсэнчлэн хүн амын улс төрийн оролцоо нэмэгдэн иргэдийн сонгуулийн эрх өргөжихийн хэрээр сонгуулийн үйл ажиллагааг гардан зохион байгуулах зориулалттай тусгай бүтэц болох “кокус"ыг байгуулах хэрэгцээ улс төрийн намд тулгардаг ажээ. М. Острогорский “кокус" байгуулагдсанаар улс төрийн намд эрх мэдлийн төвлөрөл явагдаж бюрократчлагдах замд эргэлт буцалтгүй орж олигархжих үйл явц өрнөдөг байна.

Тэгвэл германы судлаач Р.Михельс “Ардчиллын нөхцөл дэх улс төрийн намын социологи”" хэмээх гол бүтээлдээ тэр үеийн Европ тив дэх социал-демократ намууд болон үйлдвэрчний эвлэлийн байгууллагыг судлах үндсэн дээр нийгмийн томоохон бүтэц зохион байгуулалт олигархи хандлагатай болохыг тогтоосон. Тэрээр нийгэм ба төрийг ардчиллах зорилготой улс төрийн байгууллагын хувьд социалдемократ нам дотоод ардчиллыг дээдэлдэг гэж үзэж байсан боловч судалгааны явцад түүний санал бодол хувиран өөрчлөгдөж, зүүний үзэл баримтлалтай энэхүүулс төрийн байгууллага барууны “хөрөнгөтний” үзэл баримтлал бүхий намын нэгэн адил олигархи хандлагатай болох, дарангуйллын удирдлагын тогтолцоонд шилжих үйл явц гардагийг нотолжээ. Тэрээр энэ үйл явц дараахь шалтгаан нөхцөлтэй болохыг тогтоосон байна. Үүнд:

Нэгд, намын эгнээ нь биеийн хүчний хөдөлмөр эрхлэхээс зайлсхийгч “жижиг хөрөнгөтний элемент”-ээр өргөжиж, өмч хөрөнгө бүхий сонгогчдоор тэлснээр ажилчин ангийн эрх ашгийг хамгаалагч байр сууринаас олон түмний популист хэв маягийн нам болон хувирснаар намын хөтөлбөр, нийгмийн чиг баримжаа нь өөрчлөгддөг; хоёрт, урьд өмнө биеийн хүчний хөдөлмөр эсвэл бизнес эрхэлж байсан хүмүүс намын ажилтан, удирдах албан тушаалтан, намын хэвлэлийн төлөөлөгч, эрхлэгч болж дэвшин оюуны хөдөлмөр эрхлэх болсноор “барууны”, хөрөнгө мөнгөтөй хүмүүсийн эрх ашгийг хамгаалах байр суурь, үзэл баримтлалд шилжихэд тухайн нам ажилчдын эрх ашгаас ухардаг; гуравт, сэхээтэн болон хөрөнгөтний жижиг ба дунд давхрагын төлөөлөл социалист намд олноор нэгдэн орсноор тухайн нам ажилчдын эрх ашгаас ухарч хөрөнгөтний намын шинжийг олсноор олигархждаг гэж үзжээ.

Түүнчлэн Р.Михельс улс төрийн байгууллагын олигархи хандлагын сэтгэл зүйн учир шалтгааныг тогтоосон байдаг. Энэ нь нэг талаас намын жирийн гишүүдийн идэвхгүй үлбэгэр байдлаас урган гарсан бусдаар удирдуулан жолоодуулах, залж чиглүүлүүлэх хүсэл эрмэлзэл, нөгөө талаас намын дээд удирдлагын хэсгийн мэдээллийн давуу тал, эрх мэдэлд тэмүүлэх хүсэл сонирхол зэрэг нь улс төрийн намын олигархжих чиг хандлагын сэтгэл зүйн сэдэл, шалтгаан болдог гэжээ. Мөн тэрээр энэхүҮ хандлагын техникийн шинжтэй учир шалтгааныг ч нээн илрүүлсэн байдаг. Тухайлбал, улс төрийн намын гишүүдийн тоо өсөн нэмэгдэх, дотоод бүтэц зохион байгуулалт боловсронгуй болох, намын өмнө тулгарч буй зорилт нарийсч, асуудал бэрхшээл тулгарах хэрээр аливаа шийдвэр, бодлого цөөн хүн, намын дээд удирдлагын явцуу хүрээнд шийдэгдэхэд хүргэж, намын

3. острогорский М. “Демократия и организачия политических партий” М.1937., Т. №1,2.

4. Michels R. "Politikal Parties:Sociologial Stady of the Oligarchial Tendencies of Modern Democracy., Leipzig., 1911. 
элит хэсэг намын гишүүд дэмжигчдээсээ хүссэн хүсээгүй зайлшгүй зай барин холдон тасрахад хүргэдэг бичигдээгүй хууль үйлчилдэг гэдгийг илрүүлжээ. Ингэснээр намын дотоод ардчилал хумигдан, хүнд суртал газар авч аливаа улс төрийн бодлого, шийдвэр гаргах хэрэг далд байдалд, цөөн хүний мэдэлд орсноор намын элит хэсэг намын олон түмнээсээ тасарч цөөнхийн ашиг сонирхолд үйлчлэх болсноор улс төрийн нам олигархждаг жамтай гэжээ. Ийнхүу Р.Михельс судалгааныхаа явцад “төлөөллийн ардчилал нь олигархийн үр хөврөлийг агуулж байдаг, олигархи бол нийгмийн бүтцүүдийн оршихуйн гарцаагүй хэлбэр“ гэж үзэж “ардчилал гарцаагүй олигархи болж хувирна"5 гэсэн дүгнэлтэд хүрснийг улс төрийн байгууллагын “олигархи хандлагын төмөр хууль” хэмээн нэрлэсэн байна. Өөрөөр хэлбэл, аливаа улс төрийн байгууллага тэр дотор улс төрийн нам нь ардчилсан болон авторитар шинжтэй эсэхээс үл хамааран цөөнхийн эрх мэдэлд орж олигархжих хувь тавилан, зүй тогтолтой болохыг шинжлэх ухааны түвшинд нотолсонд байгаа юм. Тухайн үеийн Европ тивийн либерал болон социалист намууд олон түмний эрх ашгийг илэрхийлэх, хамгаалах үндсэн үүргээ умартан цөөн хүмүүсийн “тоглоом”-ын хэрэгсэл болох нь улс төрийн байгууллагын мөн чанараас улбаатай болохыг тогтоож “хэн байгууллага гэж ярина тэр олигархи гэж ярьж буй хэрэг юм" хэмээх алдарт хэлц үгээ гаргасан нь одоо ч ач холбогдлоо алдаагүй. Гэхдээ ХХ зууны үеийн зүүний улс төрийн намууд гол төлөв ажилчин ангийн эрх ашгийг хамгаалж байсан бол орчин цагийн ихэнхи улс төрийн намууд нийгмийн дундаж давхрагад тулгуурладаг болсон боловч Р.Михельсийн онол арга зүй, судлан тогтоосон улс төрийн намын олигархжих хандлага XXI зуунд ч үйлчилсээр байгаа аж.

“Одоо улс төрийн амьдралд намууд гэдэг бүтиүүд ноёрхоод, намууд маань олигархиудын мэдлийн хэрэгсэл болж хувирах хандлага хүчтэй байна. Улсынхаа нэрийн өмнөөс, нийгмийн нэрийн өмнөөс гаднаас зээл авч улс орноо барьцзаанд тавьчихаад цөөөн хэдэн хүний эрх ашигт Үйлчлэх хандлага гарч байна"“ гэж төр нийгмийн ахмад зүтгэлтэн Д.Бямбасүрэн гуай голыг нь олж хэлж, энэхүү хандлагаас үүсэх сөрөг үр дагаварыг "Монгол Улс эдийн засгийн тусгаар тогтонолоо тавиад mуучихлаа"7 хэмээн харамсан өгүүлсэн байна.

Тэгвэл улс төрийн намын олигархи хандлагаас үүсэх дараагийн эрсдэл бүхий ноцтой үр дагавар бол улс төрийн тусгаар тогтнол алдагдахад хүргэж болзошгүйд оршиж байдаг билээ.

Манай нэгэн нэртэй төр нийгмийн зүтгэлтэн “Өнөөдөр 250 орчим жинхэнэ олигархжсан улс төр, бизнесмен гэр бүл нийт баялгийн 70 орчим хувийг хяналтдаа оруулсан судалгаа бий"я гэж олигархжилт Монгол орныг хэрхэн торлосныг онцлоод “Засаг төр туйлдаа хүртэл хямарчихлаа. Өнөөгийн болж буй үйл явдлууд өнгөн дээрээ нам доторхи олон фракцын дажин мэт харагдаж буй боловч цаагуураа нам дамжсан ашиг сонирхлын бүлгүүдийн “их зөвиилцөл” явагдаад байна. Улаан нь ијэнхэртэйгээ, баруунтан нь зүүнтэнтэйгээ аль хэдийнээс салах аргагүй “наалдан пад” болсныг ард түмэн мэддэг болж байна”, хэмээн энэхүҮ гаж үзэгдэл хэрхэн газар авч нам дамнасан олигархуудтай болсныг халаглан бичжээ.

Түүнчлэн улс төрийн хөшигний

5. УТШУ-ны дээж бичиг.-Уб., 69 дахь тал.

6. МУ-ын ерөнхий сайд асан Д.Бямбасүрэн: "Монголын тээээвэр алуурчдыс бид мартах ёсгүй" ярилилага., www. zindaa.mn.

7. Анализ сэтгүҮл., Уб., 2014 оны дугаараас Үзнэ ҮY

8. Д.Энхтүвшин-Хожимдсон ухаарал., Өглөөний сонин., 2014. 12.23., дугаар 2299(2068).

9. Б.Дамдин-Очир. -Нам дамжсан “түрийвчний нэгдэл” буюу сөрдөггүй сөрөг хүчний тухай”,, Зуунь мэдээ.,2014.11.17., №268(4895) 
цаадахыг сургаар бус бодитой мэдэх эрх баригч улс төрийн намын даргаар ажиллаж, Монгол Улсын гүйцэтгэх засаглалыг тэргүүлж явсан улс төрч нам дамнасан олигархуудтай болсныг, олигархжсан төртөй болсныг ч барин тавин баталж байв. “АН болон МАН үзэлцээд байгаа харагдавч цаагуураа эрх ашгаараа нэвт сүлбэлдсэн нэг хоёрхон хүний том эрх ашиг, том мөнгөний тоглолт байсныг өнөөдөр та бүхэн нүдээ томсгоод харвал ил байна. Ер нь энэ улс төрийн зохиомол айдас хүйдсийн цаана нам дамжсан бүлэглэлүүдийн маш олон ашиг хонжоо бий. Одоо хууль шүүх хүчний байгууллагууд, сөрөг хүчин, банк санхүу, хэвлэл мэдээлэл, олонхи, том бизнесийнхэн гээд бүхий л бодит хүч чадал нэг бүлэглэлийн гарт байгаа нь гашуун ч гэсэн үнэн. Тэдэнд зөвхөн бүлэглэлийн эрх ашиг чухал учраас нийгэмд өөр зарчимтай, үнэт зүйлтэй хүн гарахаас үхтлээ айж, ямар ч үнээр хамаагүй тэр хүний нэр хүндэд халдах, дарах болсон"10 гэсэн ноцтой мэдээллийг ХMХ-ээр олон түмэнд тухайн үед хүргэж байлаа.

Нам хэмээх энэхүу улс төрийн институтэд олон нийт эргэлзэх болжээ. ШУА-ийн ФХ-ээс 2012 онд зохион байгуулсан "Нийслэлийн сонгогчийн дүр төрх” хэмээх олон нийтийн санаа бодлын судалгаагаар намуудад итгэх сонгогчдын итгэл дэмжлэгийн түвшин, шинж төлөвийг нягтлан үзэхэд судалгаанд оролцсон иргэдийн "60 хувь улс төрийн намаас залхах, аль ч намыг дэмжихгуй байх хандлагатай” 11 байсан бол хоёр жилийн дараа энэ бодол нь улам лавширчээ. Тухайлбал,"Сант марал” сангийн 2014 оны сүүлээр хийсэн судалгаагаар “улс төрчид, намууд иргэдийн итгэлийг бүрмөсөн алджээ”"12 гэсэн дүгнэлтэд хүрсэн нь олон түмний дунд энэхүү байгууллагын нэр хүнд ямар хэмжээнд очсоныг харуулж байна.

Иргэдийн дунд монголчуудыг хооронд нь талцуулсан олон нам байх шаардлагагүй, цөөн хэдэн нам байхад л хангалттай гэх санаа бодол ихэд дэлгэрсэн. Түүгээр ч зогсохгүй иргэдийн тодорхой хэсэг ер нь нам гэх улс төрийн байгууллага огт хэрэггүй хэмээн үзэх болсноор тус байгууллагын үйл ажиллагааг хуулиар хориглох тухай ч яригдах болсон төдийгүй “зарим үед намгүй нийгэм байгуулах тухай санал цухалзаж эхэллээ” 13 гэдгийг зарим судлаачид тэмдэглэсэн бол дээр дурдсан социологийн судалгаанд оролцогчдын тодорхой хэсэг намгүй нийгэмд шилжих тухай бодох болжээ. Тухайлбал, судалгаанд оролцсон иргэдийн “37,0 хувь намгүй нийгмийг хүлээн зөвшөөрсөн нь" 14 эл сэдэв нийгэм улс төрийн нэн тулгамдсан асуудал болж хувирсныг харуулж буй хэрэг юм.

2013 онд ФХ-ийн судлаачдын багаас Монгол дахь иргэний нийгмийн төлөвшлийн асуудлыг судлах явцад хийсэн социологийн судалгаагаар улс төрийн намууд гишүүдийнхээ санаа бодлыг харгалздаг эсэх талаар асууж тодруулахад гишүүдийнхээ саналыг харгалздаг гэж дөнгөж 10,4 хувь нь хариулсан бол “гишүүдийнхээ саналыг огт харгалздаггүй гэж 18,3 хувь”, “дарга бүх асуудльг шийддэг гэж 25,5 хувь” нь үзсэн байхад судалгаанд оролцсон иргэдийн "43,3 хувь нь улс төрийн намууд бодлого шийдвэр гаргахдаа гимүүдийнхээ саналд ач холбогдол өгдөггуй" 15 гэж үзэж байгаа зэрэг нь Монголд үйл ажиллагаа явуулж буй намууд олигархи хандлагатай болсныг харуулж буй хэрэг юм.

2014 онд МУИС-ын судлаачдын багаас зохион байгуулсан судалгаагаар улс төрийн

10. Экс ерөнхий сайдын таван тайлбар. -Үндэсний шуудан., 2015.02.26 №036 (2221).

11. Нислэлийн сонгогчийн дүр төрх. -ШУА.,ФСЭЗХ., Уб.,2012., 49 дахь тал.

12. “Зууны мэдээ” сонин.- 2014.12.25., №297(4924).

13. vір76 эксперт сэтгүүл .-С.Мөнхбат “Намгүй нийгэм байгуулах тухай санал иухалзаж эхэллээ”., Уб., 2015. № 04., 10 дахь тал

14. Нислэлийн сонгогчийн дҮр төрх.-ШУА.,ФСЭЗХ., Уб.,2012., 51 дэх тал.

15. Монгол дахь иргэний нийгмийн төлөвщлийн философи,улс төр, эрх зүйн асуудал.-Уб.,2014., 145 дахь тал. 
намууд олон түмний ашиг сонирхлыг хамгаалж, илэрхийлж чадаж байгаа эсэхийг судлан тогтооход судалгаанд оролцсон 3203 иргэний 10 орчим хувь л “илэрхийлж байгаа" гэж үзсэн бол 45,3 хувь “үгүй"16 гэж хариулсан нь эл улс төрийн байгууллагад иргэдийн итгэл алдарсан төдийгүй намуудын нийгмийн хэрэгцээ шаардлагад эргэлзэх болсныг илтгэн харуулж буй бус yу.

2015 оны 3-р сарын 27-ноос 4-р сарын 12-ны хооронд Улаанбаатар хот болон Хэнтий, Увс, Төв, Өвөрхангай, Архангай, Дундговь аймгийн нийт 1200 иргэнийг хамруулан хийсэн Сант Марал сангийн “Улстөрийн барометр" судалгааны дүнг харахад юун түрүүн тэргүүлэгч улс төрийн хүчин байхгүй болсныг харж болно.

Нэн ялангуяа УИХ, Ерөнхийлөгч, Засгийн газар гээд улс орны гурван том эрх мэдлийг атгаж байгаа Ардчилсан намын рейтинг байж болох доод түвшиндээ хүрчээ. Ардчилсан нам ердөө жилийн дотор нийслэлийн сонгогчдын итгэлийг бараг тавин хувь алджээ. Гэхдээ Ардчилсан намын дэмжигчид гол сөрөг хүчин МАН руу шилжсэн ҮҮ гэвэл бас үгүй. МАН-ын рейтинг Улаанбаатар хотод 16.2, хөдөөд 25.4 байна. ${ }^{17}$

Судалгааны энэхүҮ дүнгээс төр, засгийн эрх мэдлийг атгаж байгаа төрийн гурван өндөрлөгт ард түмэн итгэж найдахгүй, тэднийг ард түмнийхээ төлөө юм хийж чадна гэдэгт итгэл алдарч байна гэдэг хамгийн энгийн бөгөөд болитой нэгэн дүгнэлтийг хийж болно. ${ }^{18}$

Тэгэхээр өнөөдөр жирийн иргэд улс төрийн намаас татгалзах болсноос гадна төрийн тэргүүнээсээ эхлээд улс төрчид болон судлаачдаас улс төрийн намуудыг татан буулгаж шинээр бүртгэх санаачилга гаргаад эхэлсэн бол шинээр улс төрийн нам үүсгэн байгуулж буй улс төрчид бүр эрс тэрс санал гаргах болжээ. “Явиуу эрх ашгаар хуйвалдан нэгдсэн, ард түмнээ хуваан дайсагнуулсан өнөөгийн популист улс төрчдийг энэ тавцангаас иэээрлэж, улс төрийн үхширсэн соёльг өөгшүүлэн тэжэээч намуудыг улс төрөөс шахан гаргах"” явдал бол “Хөгжил-Хүн” клубын гишүүдийн улс төрийн үндсэн зорилго хэмээн тунхаглажээ.

2016 оны УИХ-ын сонгуулийн өмнө ФХийн судлаачдын багаас зохион байгуулсан "УИХ-ын сонгууль ба сонгогчид" социологийн судалгааны дүнгээс үзэхэд улс төрийн намд хандах иргэдийн хандлага бүхэлдээ тааруухан намд итгэхээ больсон, ямар нэг намыг дэмждэггүй, дэмжихгүй гэж байгаа нь хотод 53,3 хувь, хөдөөд 33,4 хувь нь байлаа.

Энэ бүхэн нь улс төрийн намыг цаашид хэрхэх талаарх олон нийтийн үзэл бодол, байр суурийн зөрүүтэй байдал нь аажмаар арилж, ижил төстөй санаа бодол руу ойртох хандлага ажиглагдаж буй нь намгүй нийгэмд шилжих цаг бидний төсөөлж байгаагаас илүү ойрхон ч байж мэднэ

Авторитар, тоталитар дэглэмтэй болон хаант засаглалтай цөөн хэдэн улс орныг эс тооцвол “намгүй нийгэм” хаана ч байдаггүй гэдэг боловч зөвхөн монголд яагаад байж болохгүй гэж.

Монгол Улсын төрийн түүхийн олон үеийн туршид Монголчууд нам хэмээх улс төрийн байгууллагаас ангид оршин төр улсаа засан тохинуулж, ахуй амьдралаа төвхнүүлж ирсэн баялаг уламжлалтай бол намтай нийгэмтэй хувь заягаа холбосон түүх ахар богино ажгуу. Намаар удирдан жолоодуулалгүй, марксизмаар малаа маллахаа заалгалгүй болоод л байсан

Харин 1921 онд гадны улс төрийн хүчний шууд заавар, оролцоотойгоор Монгол улсад анхны нам байгуулагдсан цагаас 90-ээд он хүртэлх хугацаанд нэг

16. Монголын нийгмийн хөжлийн өнөөгийн төлөв, ияаашдын хандлага.-МУИС., НШУС., Уб., 2014.

17. News week сонин.- 2015.04.20.

18. Өдрийн сонин.-2015.04.20., №79(5005).

19. Өглөөний сонин.- 2015. 02.16. № 031 (2104). 
нам, нэг үзэл суртлын ноёрхолд өөр ямар нэгэн нам байх ёсгүй, тэгэх тусмаа намгүй амьдралыг төсөөлдөггүй байсан. Ардчиллын ачаар коммунист намаас өөр нам байж болохыг ойлгож, сайн дурын үндсэн дээр эвлэлдэн нэгдэн янз бүрийн урсгал чиглэл бүхий улс төрийн нам үүсгэн байгуулж, хорь гаруй жил олон намын тогтолцоонд дасан зохицон амьдарсаар ирлээ.

Гэвч өнөөдөр манай намуудад өнөөдөр язгуур үндсээр нь шинэчлэлт зайлшгүй шаардлагатай. "Монголын намууд үйл ажиллагааны хөтөлбөр, хөтөлбөрөөс ҮҮдсэн бодлого, бодлогоос ҮҮдсэн шийдвэр, шийдвэрээс үүдсэн байр сууриа нэн тодорхой болгож, түүнийгээ цаг тухайд нь прагматик агуулгаар ягштал хэрэгжүүлж чадаж байж гэмээн томоохон суурь шинэчлэлийг хийж чадах юм"20.

Улстөрийн намууд бүтэц, зохион байгуулалт, намын ажлын арга барил,үйл ажиллагаагаа шинэчилж байж олон нийтийн алдагдсан итгэлийг олж авна.

Олон түмний намаас татгалзаж, хатуу гишүүнчлэлгүй баруун Европын улс орнуудын “өргөн хүрээний нам”, “бүхнийг шүүрэгч"21 бодлогын намыг илүүд үзэх болсон орчин цагийн чиг хандлагад нийцэх шаардлагатай.

20. Д. Болд-Эрдэнэ.-Захидлаас үүдсэн намын тухай шүүмжлэлт бодрол. www.http://nud.mn/news.

21. Мөн тэнд.

Ашигласан бутээлийн жагсаалт

1. Ш.Лувсанвандан "Орос монгол толь"., Улсын хэвлэлийн газар., Уб., 1982.

2. Ожегов “Толковый словарь русского языка".,М., 1996.

3. Орос монгол толь. Уб., 1982., Монгол хэлний товч тайлбар толь.Уб.,1966.

4. Ё.Довчин Улс төрийн үг хэллэг нэр томьёоны толь.УБ., 2005.

5. Острогорский М. “Демократия и организация политических партий” М.1937., T. №1,2

6. Michels R. "Politikal Parties:Sociologial Stady of the Oligarchial Tendencies of Modern Democracy., Leipzig., 1911

7. Краткий политтический словарь.-М.2009.,Современная западная соииология словарь.-М., 1990

8. УТШУ-ны дээж бичиг.-Уб., 69 дахь тал

9. МУ-ын ерөнхий сайд асан Д.Бямбасүрэн:"Монголын тэжээвэр алуурчдыг бид мартах ёсгүй” ярилилага.,www. zindaa.mn

10. Анализ сэтгҮҮл., Уб., 2014

11. Д.Энхтүвшин-Хожимдсон ухаарал., Өглөөний сонин., 2014. 12.23., дугаар 2299(2068)

12. Б.Дамдин-Очир. -Нам дамжсан “түрийвчний нэгдэл” буюу сөрдөггүй сөрөг хүчний тухай”., Зууны мэдээ.,2014.11.17., №268(4895)

13. Экс ерөнхий сайдын таван тайлбар. -Үндэсний шуудан., 2015.02.26 №036 (2221)

14. Нийслэлийн сонгогчийн дүр төрх. -ШУА.,ФСЭЗХ., Уб.,2012

15. “Зууны мэдээ” сонин.- 2014.12.25., №297(4924)

16. viр76 эксперт сэтгуүл.-С.Мөнхбат "Намгүй нийгэм байгуулах тухай санал иухалзаж эхэллээ”., Уб., 2015., № 04

17. Монгол дахь иргэний нийгмийн төлөвилийн философи,улс төр, эрх зүйн асуудал.-Уб.,2014

18. Д.Болд-Эрдэнэ.-Захидлаас үүдсэн намын тухай шүүмжлэлт бодрол. www.http://nud.mn/ news 